瀬 尾 明 彦*, 梯 正 之*, 水 流 聡 子*
吉 永 文 隆*

\title{
ANALYSIS OF MEASURING CONDITIONS OF SURFACE ELECTROMYOGRAM USING MATHEMATICAL MODEL
}

\author{
Akihiko SEO,* Masayuki KaKeHASHI,* Satoko TSURU* \\ and Fumitaka Yoshinaga*
}

To study the measuring conditions of surface electromyogram for work analysis in the field of industrial health, the effect of electrode fixation, electrode distance and electrode-muscle distance were studied using a mathematical model. The results were as follows;

1) The output waveforms of two electrode fixed models, i.e., parallel-fixed model (two electrodes were fixed in parallel to the direction of the muscle fibers) and transverse-fixed model (two electrodes were fixed in transverse to the direction of the muscle fibers) were compared. The maximum output and rectified integrated output of the parallel-fixed model were 2.59 times and 1.2-1.5 times larger than those of transverse-fixed model, respectively. The high output area of the parallel-fixed model was only one round area, but the areas of transverse-fixed model were four round areas which were wider than the area of the parallel-fixed model. The rectified integrated output of the parallel-fixed model was more affected by the location of neuro-muscular junction than that of transverse-fixed model when the electrodes were fixed near the neuro-muscular junction.

2) The rectified integrated output increased by electrode distance, and the changing rate of the rectified integrated output by electrode distance was particularly large when the electrode distance was shorter than $2 \mathrm{~cm}$. The effect was quite similar between the parallel-fixed model and the transverse-fixed model.

3) The rectified integrated output decreased by electrode-muscle distance, and the changing rate of rectified integrated output by electrode-muscle distance also increased when the electrodemuscle distance was short. The effect of electrode-muscle distance was not so large compared with the effect of electrode distance.

Key words : electromyogram; mathematical model; measuring condition

\section{I.はじめに}

表面筋電位（以下，EMG）は，労衝衛生の分野で腰部 負担や上肢負担の評価のために広く使用されている1 4). EMG は，等尺性収縮ではそのレペルと張力が比例関俰 にあるため姿勢保持作業の負担評価に主に利用されてき た. しかし最近は EMGが高いことは筋収縮が強く負担

* 広島大学医学部公衆衛生学教室

平成 4 年 5 月 11 日受付

* Department of Public Health, Hiroshima University School of Medicine

Received for publication, May 11, 1992
が高いと単純に解釈することも可能なことから，姿樊保 持作業拨定せずと多様な姿勢変化を伴ら作業の負担評 価にも広く利用されつつある

姿勢変化を伴う作業の EMG を測定する場合，姿樊炕 よっては皮虔が伸展して双極誘導の 2 つの電極の間の距 離（以下，電極間距離）が延長したり，皮下脂肪が压排 されて電極から筋までの距離（以下，電極筋間距離）が 変化するなど測定条件がさまざまに変化する，通常の EMG 測定では電極間距離を 2 5 cm にするが, EMG が電極間距離に応じて変化することはよく知られてい る8!: また電極筋間距離も EMG に影響し，皮下脂肪の 


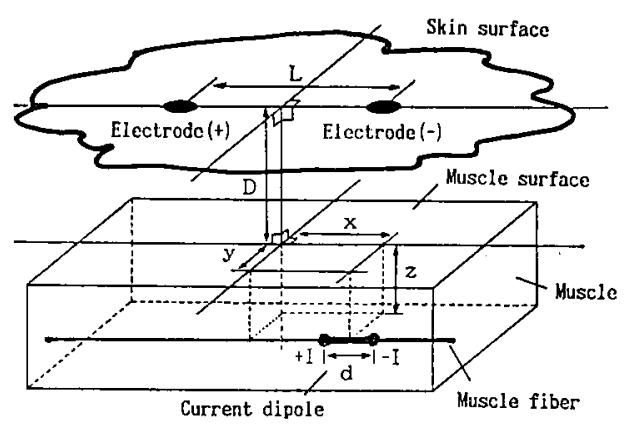

Fig. 1. Parallel-fixed model of surface electromyogram.

薄い部分の EMG は一般に高い傾向がある. 電極の固定 法についても，通常は $2 つ の$ 電極を筋線維の走行方向に そって固定することが多いが，姿枩変化による関節の屈 曲や伸展で電極間距離が変化する可能性のある場合は， その影響を避けるために筋線維の走行方向に直交するよ らに電極を固定すべきたとの考光むある゙".

姿勢変化を伴う作業の負担評価を EMG で行うために は、これらの要因の影響を考虑した上で利用しなければ ならないが，現在のところ十分な基礎的研究がなされて いるとは言いがたい，その理由の一つとして，実測によ りこれらの要因を精度よく検討することが困難な点があ げられる.たとえば電極間距離を変化させて EMG の変 化を測定する場合では，電極に力をかけて電極間距離を 変えると電極と皮䖉との間のインピーダンスが变化して EMG か゚安定しない，電極間距離を変えずに小さい電極 を多数配置して距離の影響を検討するとしても，小さい 電極は大きい電極に比へ皮膚との接触面積の影響を受け やすくなるので，EMG の測定誤差が大きくなるま た，電極筋間距離に影響を与えすに電極間距離のみを変 化させること自体も技術的にはかなり困難である。

このような実測による検討が困難な問題に対 し, EMG の発生過程を数学的にモデル化して解析する方法が生体 工学・制御工学・リハビリテーション医学などの分野で 広く用いられている10-14). 本研究では, 種々のモデルの うちで Lynn ら ${ }^{10)}$ にるる EMG 発生モデルを応用し, 電極の固定法による違い・電極間距離・電極筋間距離の 影響について理論的な検討を試みた。

\section{EMG 発生モデルの概要}

Fig.1 に EMG 発生モデルを示す. Lynn らによれ ば10)，EMG は筋線維方向に移動する双極子によって皮 㲊表面の 2 つの電極に誘導される電位であるとみなせ る. Lynn らの解析は 1 本の筋線維についてのるのであ

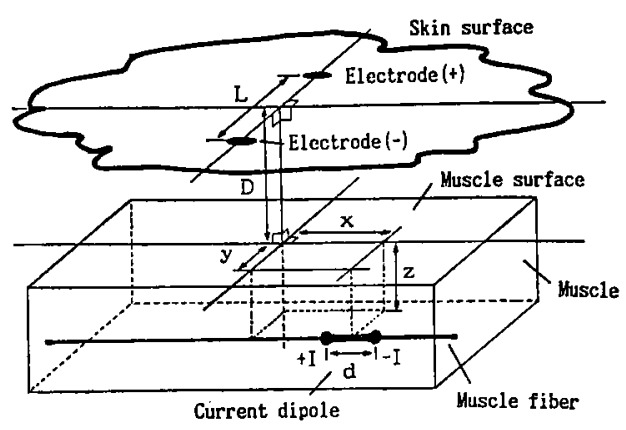

Fig.2. Transverse-fixed model of surface eletromyogram.

るが，本研究ではより奏際の筋に近い解析を行らため幅 と厚さを持つ筋に拡張して解析することとした. Fig.1 のモデルに示すように，双極子の位置は $(x, y, z)$ で表 わされる. 原点 $(x, y, z)=(0,0,0)$ は 2 つの電極の中点 の筋表面上の点とする. このモデルにおいて，ある筋線 稚に発生した双極子により電極（点とみなす）に誘導さ れる出力Vは次の式で表わされる。

$$
V=\frac{2 \rho I}{4 \pi}\left\{\left(\frac{1}{r_{++}}-\frac{1}{r_{+-}}\right)-\left(\frac{1}{r_{-+}}-\frac{1}{r_{--}}\right)\right\}
$$

ただし，

$$
\begin{aligned}
& r_{++}=\sqrt{(x+0.5 L-0.5 d)^{2}+y^{2}+(z+D)^{2}} \\
& r_{+-}=\sqrt{(x+0.5 L+0.5 d)^{2}+y^{2}+(z+D)^{2}} \\
& r_{-+}=\sqrt{(x-0.5 L-0.5 d)^{2}+y^{2}+(z+D)^{2}} \\
& r_{--}=\sqrt{(x-0.5 L+0.5 d)^{2}+y^{2}+(z+D)^{2}}
\end{aligned}
$$

$\rho:$ 筋線維電気伝導率

$I:$ 双極子電荷密度

$d:$ 双極子間距離

$L$ : 電極間距離

$D:$ 電極筋間距離

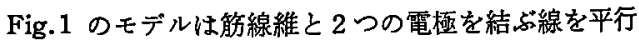
に固定したもの（以下，平行固定）であるが，筋線維と 2 つの電極を結ぶ線が直交する固定（以下，直交固定） はFig.2のようになる，直交固定でのVは，r++, $r_{+-}$ $r_{-+}, r_{--}$が次のようになる以外は平行固定と同じであ る.

$$
\begin{aligned}
& r_{++}=\sqrt{(x-0.5 d)^{2}+(y+0.5 L)^{2}+(z+D)^{2}} \\
& r_{+-}=\sqrt{(x+0.5 d)^{2}+(y+0.5 L)^{2}+(z+D)^{2}} \\
& r_{++}=\sqrt{(x-0.5 d)^{2}+(y-0.5 L)^{2}+(z+D)^{2}} \\
& r_{--}=\sqrt{(x+0.5 d)^{2}+(y-0.5 L)^{2}+(z+D)^{2}}
\end{aligned}
$$

実際の筋では，神経筋接合部で発生した電気的興畒は 筋線維の走行にそって両方向に伝達する．Fig.1 と Fig. 
2 のモデルは1つの双極子のみを取り扱っているが，こ れは神経筋接合部が電極から十分遠い場所にある場合と みなせる．神経筋接合部を考虑する場合は，神経笳接合 部で発生した $2 つ の$ 双極子が同し速度で逆方向に移動す るとみなせばよい。

労働衛生の分野では，乞のままの筋電位波形上り整流 皘分筇電位（以下， $V_{\mathrm{i}}$ ）が利用されることが多い，1本 の筋裸維に発生した 1 個の双極子による $V_{1}$ は，双極子

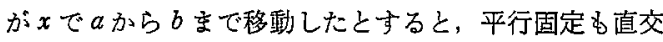
固定も $V$ の絶対値を皘分した次の式で与えられる.

$$
V_{1}=\int_{a}^{b}|V| d x
$$

ある幅と厚みを持った筋の中を多くの双極子が移動し ていく場合は, $x \cdot y \cdot z$ による三重積分値が V 1 となる.

\section{III. 方 法}

\section{1. パラメータの決定}

モデル解析を行うための各パラメータの值について は，計算上，次の上らに決定した。

1）電極間距離 $L$ : 使用する電極の大きさに応して短 絡しない距離に設定される。ここでは $0 \sim 10 \mathrm{~cm}$ の範丑 をとることとした。

2）電極筋間距離 $D:$ 皮膚と皮下脂肪の厚さで決 る.ここでは $0.5 \sim 5 \mathrm{~cm}$ とした。

3）筋の大きさ：これは $x, y, z$ の範囲で規定され る. $x$ は筋線襍の長さに相当するので, $-20 \sim+20 \mathrm{~cm}$, $y$ は筋の幅飞相当するので $-10 \sim+10 \mathrm{~cm}, z$ は筋の厚 さに相当するので 0 $5 \mathrm{~cm}$ の範囲をとることとした。

4）双極子間距離 $d:$ これ沉いては实測值はない。 単一筋線維の電気的興䳽は持続時間が約 $1 \mathrm{~ms}$ で伝導速 度か $4.7 \mathrm{~m} / \mathrm{s}^{15)}$ であることからその幅は $0.47 \mathrm{~cm}$ とな るか゚，これが双極子間距離に相当するとみなしてここで は $0.5 \mathrm{~cm}$ とした。なお Lynn らはその根拠は明らかに していないが $0.6 \mathrm{~cm}$ 相当の值を利用している.

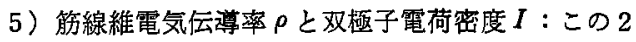
つのパラメータは出力の絶対値を規定する係数であるが
実測值は報告されていない，本研究では絶対值を求める 必要はないので, $2 \rho I / 4 \pi=1$ として解析することとし た.

\section{2. 解析方法}

前述のパラメータを利用して次の解析を行った.

1）固定法に上る出力の違い：1つの双極子が $x=-$

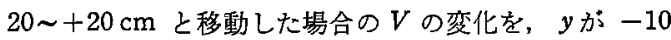
$\sim+10 \mathrm{~cm}$ の範团で求めた．また，笳線維上の位置 $x=$ $0 \sim 10 \mathrm{~cm}$ 飞神経筋接合部があり，そこから双方向炕双 極子が $20 \mathrm{~cm}$ 移動した場合の $V$ の变化をも求めた. い ずれの場合む， $L=3 \mathrm{~cm}, D=2 \mathrm{~cm}, z=0 \mathrm{~cm}$ とした。

2) 電極間距離 $L$ と $V_{\mathrm{i}}$ の関係: $D=2 \mathrm{~cm}$ とし， $L か ゙$

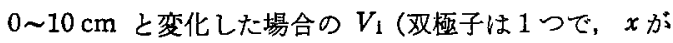
$-20 \sim+20 \mathrm{~cm}, \quad y$ が $-10 \sim+10 \mathrm{~cm}, z$ が $0 \sim 5 \mathrm{~cm}$ で変化した場合の $V$ の絶対値の三重積分値）を求めた。

$3 ）$ 電極筋間距離 $D$ と $V_{1}$ の関倸: $L=3 \mathrm{~cm}$ と乙, $D か 30.5 \sim 5 \mathrm{~cm}$ 之变化した場合の $V_{1}$ (双極子は 1 つ で, $x$ か; $-20 \sim+20 \mathrm{~cm}, \quad y$ かi $-10 \sim+10 \mathrm{~cm}, \quad z$ が $0 \sim 5 \mathrm{~cm}$ まで变化した場合の $V$ の絶対値の三重皘分値) 求めた.

解析には、パーソナルコンピニータ Macintosh (フッ プルヌンピュータ社）のもとて作動するプログラム Mathematica ${ }^{16)}$ と, 仏島大学情報処理センターの大型 コンピュータ HITAC M-680 のもとで最適化 FORTRAN7717〕による皘分プログラムを作成して利用した。

\section{IV. 結 果}

\section{1. 固定法による違いついて}

Fig. 3 火平行固定之直交固定の各出力波形を示す. 平 行固定の $V は, 2$ つの電極の中点の位居 $(x=0 \mathrm{~cm}, y=$ $0 \mathrm{~cm})$ で最大 0.0954 となり, その前後の位置 $(x= \pm$ $3.16 \mathrm{~cm}, y=0 \mathrm{~cm})$ で最小 -0.0292 となる. したがっ $\tau, y=0 \mathrm{~cm}$ 付近の筋線維による出力波形は 3 相性とな る.これ対し直交固定の $V$ は， 2 つの電極の前後の位 直 $(x= \pm 1.29 \mathrm{~cm}, y= \pm 1.74 \mathrm{~cm})$ で最大 0.0368 ある いは最小 -0.0368 となり，2つの電極の中点を通る位
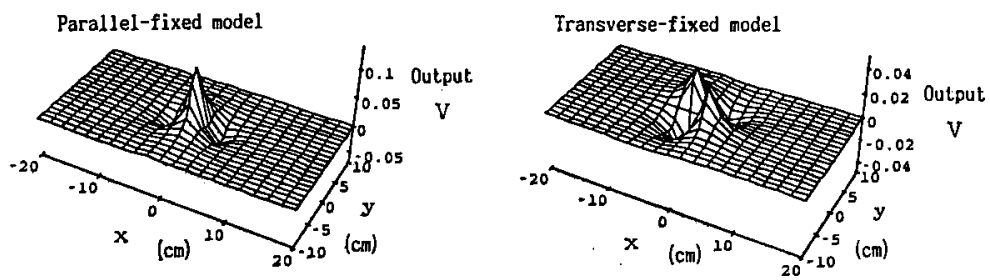

Fig. 3. Output waveforms of two fixed models. $L=3 \mathrm{~cm}, D=2 \mathrm{~cm}, z=0 \mathrm{~cm}$. 

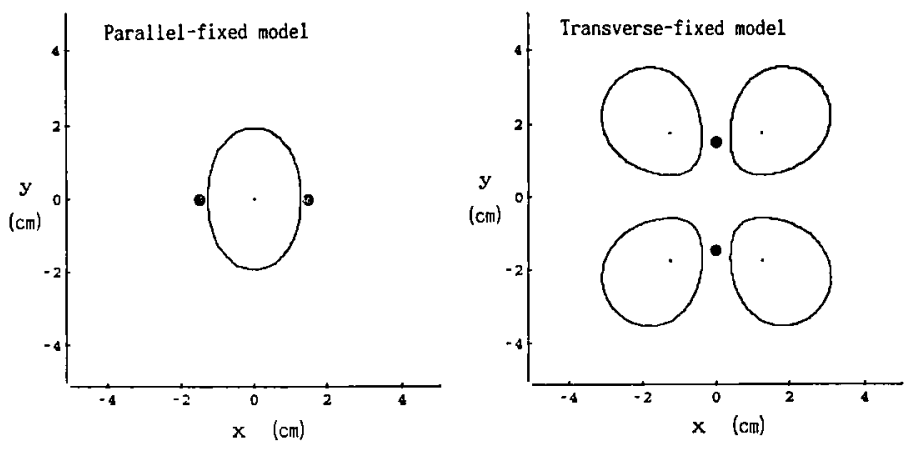

Fig.4. High output areas of two fixed models ( $L=3 \mathrm{~cm}, D=2 \mathrm{~cm}, z=0 \mathrm{~cm}$ ). The round areas are high absolute output areas of more than $50 \%$ of maximum output level.

- location of electrodes.

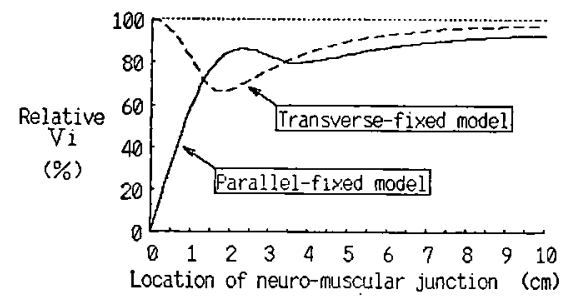

Fig.5. Relationship between location of neuromuscular junction $\left(X_{0}\right)$ and relative $V_{1}(L=$ $3 \mathrm{~cm}, D=2 \mathrm{~cm}, z=0 \mathrm{~cm})$. The relative $V_{1}\left(X_{0}\right)$ (relative $V_{1}$ at $X_{0}$ ) are calculated by the following equation; Relative $V_{1}\left(X_{0}\right)=V_{1}\left(X_{0}\right) / V_{1}$ $\left(X_{0} \rightarrow \infty\right) \times 100[\%]$. For detailed explanation, refer to text.

置 $(x=0 \mathrm{~cm}$ あるいは $y=0 \mathrm{~cm})$ では 0 となる. したが って $y=0 \mathrm{~cm}$ を除く胆線維による出力波形は 2 相性 と なる. 出力振幅の最大值で比較すると平行固定は直交固 定の 2.59 倍となっている.

Fig.4 にVの絶対值が最大值の $50 \%$ 以上になる高出 力領域を示す. 平行固定では 2 つの電極の中点を中心之 する棈円形の領域が高出力となるのに対し，直交固定で は 2 つの電極を含まない 4 つの領域が高出力となる. $y$ の幅で比較すると，平行固定は $\pm 1.91 \mathrm{~cm}$, 直交固定は $\pm 3.51 \mathrm{~cm}(0 \mathrm{~cm}$ 付近の低出力領域。含む) 之，直交 固定は 1.84 倍の幅の筋線維の興奮を特に強く反映する ことになる.

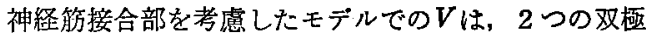
子による合成波形となるため，Fig.3 上りも複雑な波形 になる.ここでは数值的に神経笳接合部位の影響を捕ら えやすくするために，双極子位直で積分した $V_{1}$ を求め ることとした，積分は，筋線維上で神経筋接合部位固か

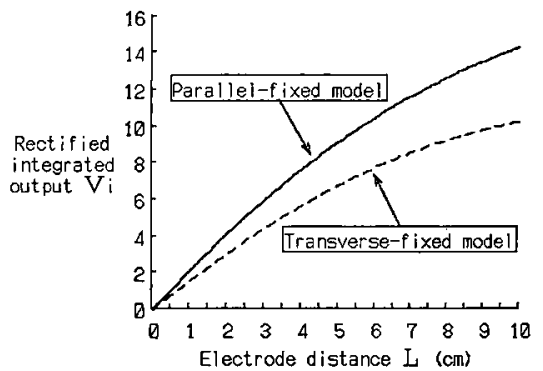

Fig.6. Relationship between electrode distance $L$ and rectified integrated output $V_{1}$.

ら2つの双極子が逆方向に $20 \mathrm{~cm}$ 移動する範国で行っ た. $y$ は，Vが最大の変動を示す位置として，Fig.3の 結果より平行固定では $0 \mathrm{~cm}$, 直交固定では $1.74 \mathrm{~cm}$ と した. Fig.5 に結果を示す. $V_{1}$ は，神経筋接合部位置 が無限遠にあるときの $V_{1}$ を $100 \%$ とした相対值で示 している. 神経筋接合部が 2 つの電極の中点から 5 6 $\mathrm{cm}$ 以上離れると $V_{1}$ は大体一定になる. しかし 0 1.5 $\mathrm{cm}$ のときは, 平行固定では 0 80\%, 直交固定では $65 \sim 100 \%$ の範囲で $V_{1}$ は変化する.

\section{2. 電極間距離 $L$ と $V_{1}$ の関係}

Fig.6 に示すように，Lが長くなるのに応して V、 高くなる. 平行固定のほうが直交固定より全体的に 1.35 〜1.39 倍のレベルであるが，曲線の形はほぽ同じであ る.

Fig.7にLが $\pm 0.5 \mathrm{~cm}$ 変化した場合の $V_{1}$ の变化率 を示す． 固定法による差はほとんどないため，2つの固 定法の曲線はほぼ重なっている，いずれの固定法におい ても $L$ が短い場合は $V_{1}$ の変化率が非常に大きく, $1 \mathrm{~cm}$ では平行固定 $98.4 \%$ ，直交固定 $98.6 \%, 2 \mathrm{~cm}$ でる平 


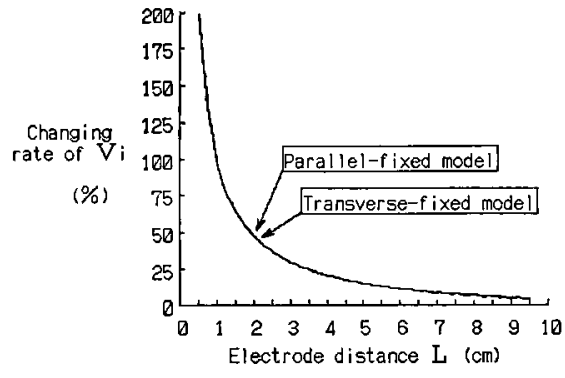

Fig.7. Relationship between electrode distance $L$ and changing rate of $V_{1}$. Changing rate of $V_{1}(L)$ ( $V_{1}$ at $\left.L\right)$ is calculated by the following equation; Changing rate of $V_{1}(L)=$ $\frac{\left|V_{1}(L+0.5)-V_{1}(L-0.5)\right|}{V_{1}(L)} \times 100[\%]$.

行固定 $47.4 \%$ ，直交固定 $47.6 \%$ の変化率となっている.

\section{3. 電糧筋間距離 $D$ と $V_{1}$ の関係}

Fig.8 に示すように，Dが長くなるのに応して $V_{1}$ は 低くなる.この傾向は $D$ がささ場合に特に強い、平行 固定のほうが亩交固定より全体的に 1.24 1.54 倍のレ ヘルであるが，曲線の形はだいたい同じである.

Fig.9 にDが $\pm 0.5 \mathrm{~cm}$ 変化した場合の $V_{1}$ の変化率 を示す. 平行固定に比べ, 直交固定の変化率は $5 \%$ 前後 大きい.いずれの固定法でもDが短いはど变化率は大き いが， $1 \mathrm{~cm}$ では平行固定 $48.9 \%$ ，直交固定 $55.3 \% 2$ $\mathrm{cm}$ では平行固定 $37.4 \%$, 直交固定 $42.2 \%$ と，Lによ る変化率に比べると小さい.

\section{V. 考察}

\section{1. 固定法について}

労衝衛生の分野の論文ではほとんどが平行固定を利用 しており值交固定を用いたものは少ない，今回の結果に より, 出力の大きさ, 限局性, 神経筋接合部の影響, 出 力の安定性の 4 点から両固定方法の比較を行う.

まず出力の大きさについては，平行固定は直交固定に 此べ, 原波形の最大值では 2.59 倍, 整流積分值 $(x, y$, $z$ の三重積分値) では 1.2 1.5 倍の出力が得られる. 最近は測定器の增幅率に余裕があるので出力が大きいこ とは決定的な利点とはならないが，周囲の電気的ノイズ が入る可能性のあるフィールドでの使用る考えるとやは り出力の大きい平行固定のほうが有利といえる.

次に EGM がどの程度限定した範囲の飭線維の興罊を 反映するかという限局性については, 平行固定は $2 つ の$ 電極の中点を中心とする 120 領域内の筋興翼を最大に 反映するのに対し，直交固定は電極と少しはなれた 4 領

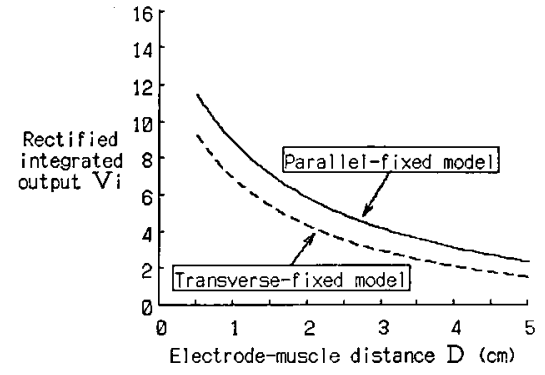

Fig. 8. Relationship between electrode-muscle distance $D$ and rectified integrated output $V_{i}$.

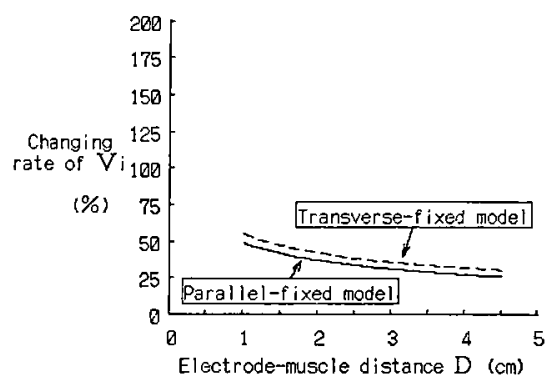

Fig.9. Relationship between electrode-muscle distance $D$ and changing rate of $V_{1}$. Changing rate of $V_{1}(D)\left(V_{1}\right.$ at $\left.D\right)$ is calculated by the following equation; Changing rate of $V_{\mathbf{i}}(D)=$ $\frac{\left|V_{1}(D+0.5)-V_{1}(D-0.5)\right|}{V_{\mathrm{i}}(D)} \times 100[\%]$.

域の筋興鹤を最大に反映する.したがって筋の限局した 㹧い領域の筋興峦を周辺の他の筋の影響を受けないよう にして捕らえようとすると，限局性のよい平行固定が望 ましいといえる. しかし逆に，比較的大きな筋の興罂を できるたけ総合的に評価しようとする場合には，限局性 の強い平行固定よりる広範な領域の筋興奮を反映する直 交固定のほうが適するといえる.

神経筋接合部の影響については, 神経筇接合部が電極 に近いといずれの固定法でも $V_{1}$ は変動しやすい，ただ し直交固定のほうが变動幅が小さく有利である.

出力の安定性については，Lの変動に対する $V_{\mathrm{i}}$ の変 動率はほとんど同じであるが，Dの変動に対する $V_{1}$ の 変動率は平行固定が直交固定よりわずかに小さい，しか し㬰際の测定において飰線稚の伸縮による影響を受けや すいのは筋線維方向に電極を固定する平行固定なので， 屈曲伸展による変化が生じやすい部位や姿勢では面交固 定のほうが望ましいと思われる。

以上まとめると, 平行固定は出力が大きく限局性がよ いが神経筋接合部や屈曲伸展の影響を受けやすいのに対 
し，直交固定は出力がやや小さく限局性は悪いが，広い 筑囲の筋の活動度を反映しやすく神経筋接合部や屈曲伸 展の影響は受けにくいという特性がある.したがってど ららかの固定法が常に優れているとはいえず，目的に応 じて使い分ける必要があると思われる。な和実際には正 確に筋線維に平行あるい㥀交して電極を固定すること はほとんど不可能なため，平行固定の成分と直交固定の 成分が混在することになる，たとえば平行固定に直交固 定の成分が混在すると，出力も限局性も低下することに なる.こういった影響も EMGの再現性や解釈の際に注 意すべきポイントになると思われる.

\section{2. 電極間距離 $\boldsymbol{L}$ の影響について}

従来のように一定の保持姿勢での湘定を比較評価する 場合は，Lが同一の状態での比较となるので，Lの影響 が問題となることは少ないと思われる，乙かしさまざま に变化する姿勢での測定結果を比較する場合は，測定部 位によっては姿棼に応じてLがかなり変化する.今回の

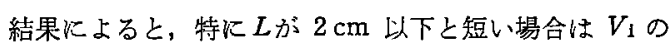
変動が非常に大きくなるので注意が必要である．Lの変 動による影響を避けるためには，前述したよらに影響を 受けにくい固定法や固定場所を選ぶことや，Lをある程 度長めにすることも重要であるら。また，Lは体表面か ら簡単に計測できるので測定後に補正する方法も考えら れる。なお非常に短いLでの測定には，皮膚の伸展・屈 曲や発汗による電極の短絡を避けるため，小さい電極を 1 つの台座に複数固定したタイプのるのがすでに利用さ れている8,18 20)。このような電極を利用すれば，Lが短 くてもその变動の影響は受けなくてすむ.

\section{3. 電極筋間距離 $D$ の影響について}

$D$ 変動による影響む，Lの变動による影響と同様に 一定の保持姿努での比較では問題とならないが，異なる 姿勢間の比較や運動中の測定では体位や肢位による皮下 脂肪の変位や体動による振動などでDが变動することが

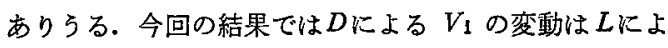
る $V_{1}$ の変動に比べると小さいが，実際の測定でどの程 度の変動が生じるか不明なため，DとLのいずれが影響 が大きいか吽定できない，ただし，屈曲の状態により 皮㖇がたるみやすい肩・頸部・些部などで測定する場 合，衣服などで電極固定部が王迫される場合，肥満者で 体位や肢位により皮下脂肪が変位しやすい場合などでは 少なくともDの変動の影響に注意をはらら必要があろ 5.

\section{4. 実際の筋電位との相違について}

今回の結果は、あくまで現象を単純化したもデルによ る解析結果であり，いくつかの点で実際の筋電位とは異
なっている.

その 1 つが電極を面積のない点とみなしていることが ある. 正確にはより厳密なモデルによる解析が必要であ るが，電極に面積がある場合のVは，特拈まかには電極 の存在する領域内の $V$ の平均値に近い值になると予想さ れる.このため, Fig. 3 に示した波形变化に比べ電極の 大きさが大きければ大きいほど滑らかで変動の小さな波 形になるはずである．電極面積が小さいと皮局との接触 抵抗の影響を受けや寸くなるが，忠実な波形記録にはで きるだけ電極が小さいらがよいことになる。

もら1つの大きな相違点としては実際の筋電位測定で は洔間的な経過で記録し積分されるのに対し，今回のモ デルでは位置的な経過で表示し積分した点がある. Fig. 3 に示した筋電位波形については，xの軸を双極子の移 動速度 (約 $5 \mathrm{~m} / \mathrm{s}$ ) で割れば, 笳電位の時間的変化とみ なせる. しかし Fig.6〜9 に示した積分電位 V」につい ては，単純には時間的経過に变換できない，実際の筋電 位は多くの筋線維上で発生している個々の興奮の総和で ある.ただし，個々の筋線維の興竇は完全にランダムに 発生するのではなく，千渉による効率低下を避けるため に，ある筋線維のブロック単位で同期して興猫するとさ れている21)。この現象をモデル化すると，ランダムなブ ロック単位で興丟する筋線維を仮定するシミュレーショ ン解析を行らことになる. しかし，十分に長い時間で相 互に干涉しない與奮がブロック単位でランダムに発生す ることは，すべての筋線維で同じ頻度で相互の干涉なく 興偪が発生することと同じとみなせる.これは位置的積 分に相当するので，結局，時間的積分と位置的積分は同 様な結果を与えるはずである。

その他， $V_{1}$ での検討では神経筋接合部を考慮しない モデルで解析している点がある. 神経筋接合部は, 負担 評価のための筋電位測定ではほとんど考應されていない ようであるが, 興奮の伝導速度の検討には重要なポイン トとして指摘されている18 202. 今回の結果によると, 特 に平行固定で 2つの電極が神経筋接合部を挟むように固 定された場合，Lの変動などで電極と神経筋接合部との 相対的位固がずれると非常に大きな变動が生じる可能性 がある.しかし電極が神経筋接合部から $4 \sim 5 \mathrm{~cm}$ 以上 離れれば, 全体的に $V_{1} か ゙ 1 〜 2$ 割低下するだけなので, Fig.6〜9 に示した結果に大きな影響はないと思われる.

\section{VI. ま とめ}

姿勢変化のある作業の表面筋電位に影垬する因子を検 討するために，数学的な筋電位発生モデルにより電極の 固定法・電極間距離・電極筋間距離の影響について検討 
し, 次の結果を得た.

1) 電極の固定法については，2つの電極を筋線維と 平行に固定する平行固定法と直交するように固定する直 交固定法とを比較した．その結果，平行固定は出力が大 きく狭い領域の筋電位を捕らえているのに対し，直交固 定は出力がやや小さいが広い領域の筋電位を捕らえてい ることが判明した。また神経筋接合部位が電極に近い と, 平行固定では特に出力が变化しやすいことる判明し た.

2）電極間距離による整流積分電位の変動について は，電極間距離が長くなるほど整流積分電位が増大して いだ.この電極間距離による变動は, 電極間距離が短い ほど大きいことが確認された，電極間距離による变動は 平行固定と直交固定でほとんど同じであった.

3 ）電極筋間距離による整流積分電位の变動について は，電極筋間距離が長くなるほど整流積分電位は低下し ていた.この変動も電極肪間距離が短い場合に大きい が，電極間距離による变動よりも小さかった。

本研究の一部は平成 2 年度文部省科学研究費補助金（課題番 号02770293）によって行われたまた，本研究の一部は第 65 回 日本産業衛生学会（1992年, 徳島）にて発表した。

\section{文献}

1）大西徳明，渡辺明彦，進藤弘基，多贺谷幸子，小木和孝， 斉藤むら子. 重量物取扱い作業者の腰部負担に関する実証 的研究. 労㗢科学 $1985 ; 61(2): 59-82$.

2) 横森 求, 钘口健治, 中川武夫, 松本忠雄, 山田信也. 直進走行中のオートバイのライダの腕の㗨張. 産業医学 $1989 ; 31: 421-428$.

3) McGill SM, Norman RW, Sharratt MT. The effect of an abdominal belt on trunk muscle activity and intra-abdominal pressure during sqat lifts. Ergonomics 1990, 33:147-160.

4) Moore A, Wells R, Ranney D. Quantifying exposure in occupational manual tasks with cumulative trauma disorder potential. Ergonomics 1991; $34: 1433-1453$.

5）徳永力婎, 請田俢一. 拐带型筋電モニター計の開発と試 用経験. 産業医学 $1988 ; 30: 774$.

6) 大西徳明, 三宅康彦, 三木 繁, 福田 妁. タハ・コ幹刈
収段作業の作業負担に関する人間工学的研究. 労働科学 $1988 ; 64: 533-543$.

7) 井谷 徽, 甲田茂樹, 竹内 研, 青山英康. 表面電極筋 電図による作業中局所筋負担評価. 産業医学 $1986 ; 28$ ： 713.

8）吉田正樹, 赤沢堅造, 藤井克彦. 整流積分筋電位の精度 改善の方法. 矤用電子と生体工学 $1988 ; 26: 25-31$.

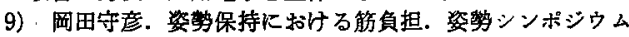
論文菓. $1971: 25-36$.

10) Lynn PA, Bettles ND, Hughes AD, Johnson SW. Influences of electrode geometry on bipolar recordings of the surface electromyogram. Med Biol Eng Comput 1978; $16: 651-660$.

11）三田勝巳，宮側敏明，赤潼久美. 急速動作開始前に括け る筋活動電位の非定常解析. 医用電子と生体工学 1987 ; $25: 15-20$.

12) 谷江和雄, 藤川昭婎, 阿部 稳, ほか。管電位の解析 (主として上腕二頭矨について). バイオメカニズム学会, 編. パイオメカニズム3. 東京：東京大学出版会, 1975 ： $73-84$.

13）渡辺 睹, 福本一朗, 池田研二, 斉藤正男, 大島正光. ストローク運動時の四肢筋の微小振動の分析. バイオメカ ニズム学会, 編. パイオィカニズム 4 . 東京: 東京大学出 版会, $1978: 69-76$.

14）楖原久司，㸺井義正，原田尚文，島野元婎. 筋電の周波 数情報を用いた多機能前腕義手の制㻟. シイオメカニズム 学会, 編. バイオメカニズム 4. 東京: 東京大学出版会, 1978: 131-138.

15）真島英信. 生理学. 東京: 文光堂, $1986: 49-75$.

16) Wolfram $S$. Mathematica : a system for doing mathematics by computer. New York: AddisonWesley Publishing Company, Inc., 1988.

17）日立繁作所. プログラムプロダクトVOS1.S, VOS1, VOS2, VOS3 最適化 FORTRAN77, HAP FORTRAN 77 言語. 横捠：日立製作所, 1984.

18) Sadoyama $T$, Masuda $T$, Miyano H. Optimal conditions for the measurement of muscle fibre conduction velocity using surface electrode arrays. Med Biol Eng Comput $1985 ; 23: 339-342$.

19) 白石 恵, 岡田守增田 正, 佐渡山覀兵. 筋電位多 点計測による体幹背部の神経支配带の分布. ヘイイオメカニ ズム学会, 編. バイオメカニズム11. 東京 : 東京大学出版 会, 1992:193-203.

20) 增田 正, 佐渡山亜兵, 白石 恵. 筋収䌅力と筋線踓伝 導速度. パイオメカニズム学会, 編. ハイオメカニズム11. 東京: 東京大学出版会, $1992: 205-211$.

21) Kanosue K, Yoshida M, Akezawa K, Fujii K. The number of active motor units and their firing rates in voluntary contraction of human brachialis muscle. Jpn J Physiol $1979 ; 29: 427-443$.

著者への通信先 : 瀬尾明彦, T734 広島市南区霞 1-2-3 広島大学医学部公䎹衛生学教室 Reprint requests to Department of Public Health, Hiroshima University School of Medicine, 1-2-3 Kasumi, Minami-ku, Hiroshima, 734 Japan (A. Seo) 